\title{
Emergent heritage: the digital conservation of archaeological sites in reservoirs and the case of the Dolmen de Guadalperal (Spain)
}

\author{
Enrique Cerrillo-Cuenca ${ }^{1 *} \mathbb{D}$, José Juan de Sanjosé Blasco², Primitiva Bueno-Ramírez ${ }^{3}$, \\ Juan Antonio Pérez-Álvarez ${ }^{4}$, Rodrigo de Balbín Behrmann ${ }^{3}$ and Manuel Sánchez-Fernández ${ }^{2}$
}

\begin{abstract}
The dolmen of Guadalperal (Spain) became well known in 2019 when the waters of the reservoir in which it had long been submerged became so depleted as to leave it above water and highly visible. This gave rise to great media and social polemic. In this study, we deal with the'recovery' of the dolmen using digital techniques, including a strategy of geometrical documentation of long, medium and short-range through the use of terrestrial laser scanning (TLS) and photogrammetry. The result is a set of products that trace the changes that have taken place in the monument since its excavation in 1925, the identification of conditions affecting it and the acquisition of new information on the decorated supports that formed part of the megalithic architecture. To do so, the time during which it was accessible (i.e., not underwater) was used to acquire the only heritage information currently available on the monument. This new information offers a complete assessment of a megalithic monument using a protocol that is exportable to other sites submerged in lakes or reservoirs.
\end{abstract}

Keywords: Digital recording, Submerged archaeological heritage, Megaliths, Climate change

\section{Introduction}

Megalithic heritage can be seen as global imagery made up of symbols [1] chronological developments and similar landscape notions across Western Europe [2, 3]. It has the unquestionable capacity to determine the meaning of the landscape beyond its prehistoric uses to produce a shared perception [4]. Under this premise, the protection of and research into megalithic sites must relate to the cultural peculiarities of each region [5-10]. This study responds to the need to harmonize these social requirements by the incorporation of digital geometric documentation in an unusual case as is the conservation of archaeological assets lying over the waters of reservoirs.

\footnotetext{
*Correspondence: enriqcer@ucm.es

${ }^{1}$ Department of Prehistory, Ancient History and Archaeology,

Complutense University of Madrid, Madrid, Spain

Full list of author information is available at the end of the article
}

The case chosen, the dolmen of Guadalperal, made the media headlines during the summer of 2019 when the fall in the water level of the reservoir of Valdecañas (Spain) led to the emergence above the water of this famous monument (Fig. 1). The assessment of the preservation of the dolmen was undertaken by the Spanish Ministry of Culture, specifically the Spanish Institute of Cultural Heritage (IPCE), and a group of specialists, including the undersigned. Although the archaeological site was already well known to professionals in the field, the media presented it as a discovery and an opportunity to promote cultural tourism in the region. Despite the evident error, the national and international media compared it with Stonehenge promoting a vivid social debate on the convenience of relocating the sepulchre to a place somewhere out of the reservoir.

Thus, the current scenario in which the management of hydric resources and climate change is creating an unprecedented need to safeguard cultural heritage in
Springer Open

(c) The Author(s) 2021. Open Access This article is licensed under a Creative Commons Attribution 4.0 International License, which permits use, sharing, adaptation, distribution and reproduction in any medium or format, as long as you give appropriate credit to the original author(s) and the source, provide a link to the Creative Commons licence, and indicate if changes were made. The images or other third party material in this article are included in the article's Creative Commons licence, unless indicated otherwise in a credit line to the material. If material is not included in the article's Creative Commons licence and your intended use is not permitted by statutory regulation or exceeds the permitted use, you will need to obtain permission directly from the copyright holder. To view a copy of this licence, visit http://creativecommons.org/licenses/by/4.0/. The Creative Commons Public Domain Dedication waiver (http://creativeco mmons.org/publicdomain/zero/1.0/) applies to the data made available in this article, unless otherwise stated in a credit line to the data. 


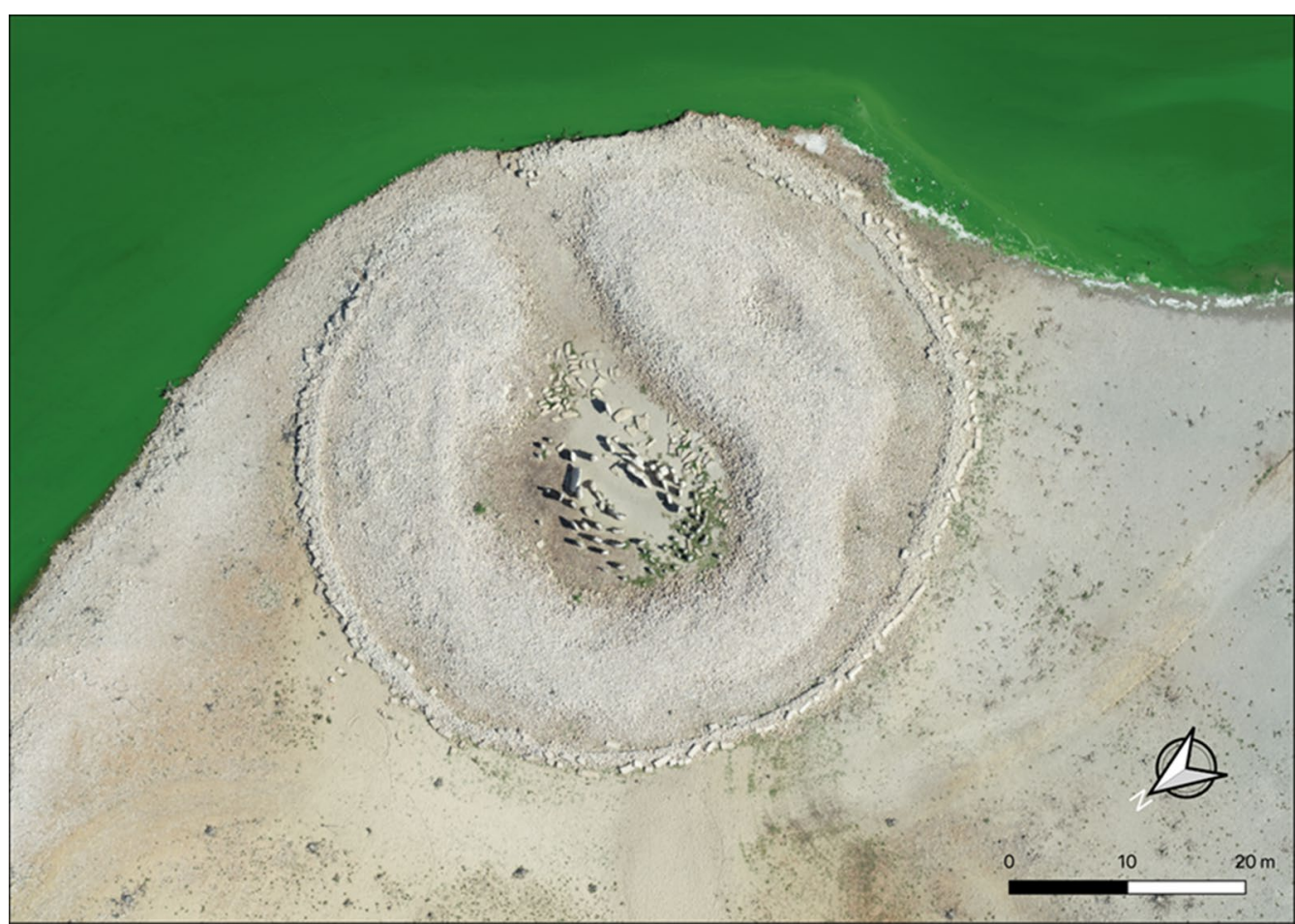

Fig. 1 Orthoimage of Dolmen de Guadalperal, images taken during September 2019. The image has been composed using the procedures described in this paper

coastal areas of Western Europe [11-14] Situations such as that of the dolmen of Guadalperal will be repeated in the future and make it necessary to design research strategies that improve knowledge of cultural goods in affected territories and consolidate management heritage policies under the pressing needs of conservation $[15,16]$ This is a complex issue, which involves social and legal aspects associated with archaeological knowledge and heritage management.

Geometric documentation of cultural heritage in the face of any risk that threatens its preservation is certainly not new $[12,17,18]$. Some of this work includes the use of photogrammetry on coastal sites in the face of erosion due to climate change [19, 20]. However, there is no previous literature on the geometrical documentation of submerged archaeological assets in reservoirs. Additionally, the digitalisation of European megalithic heritage is a line of work that has been pursued at different levels. On the one hand, initiatives have been developed to document the architectural elements of megaliths using photogrammetric [21-23] and laser scanning techniques, sometimes using BIM technology [24] to unravel aspects of their construction. On other occasions, digital products have been used to simulate the relationship between the monuments and the natural lighting [25]. Finally, perhaps the most exploited field is that of the analysis of engravings and paintings found on the slabs of the megaliths, where there is a certain tradition of analysis developed in recent years in countries such as Spain [26], Portugal [27], France [28] or Ireland [29].

Looking beyond the final decision on the conservation of the site, a line of work is put forward to provide a model interpreting the site of the dolmen of Guadalperal in a reliable way as possible and as it would have appeared in its original state, together with the transformations caused by its flooding. This line of works comprises the generation of high-quality geometric documentation as well as monitoring the damage produced on the monument by different agents like weathering. In this case, the study we present here aims to use geometric recording techniques to establish continuous monitoring of the Guadalperal Dolmen. The novelty lies in the establishment of a control system in which each of the parts of the monument can be individualised in order to observe the changes that changes in conditions may cause. This includes the documentation of the area surrounding the monument, of its slabs, but also of the engravings found on some of them. This approach involves a combination of different techniques that are brought together in this work for the purpose of research but also for monitoring of the changes that the monument may undergo. 


\section{The archaeological and historiographic context of Guadalperal}

The megalithic sites from the inner basin of the Tagus River have been the object of archaeological research programs for decades [30]. A chronological diversity of monuments built from the end of the 5th to the end of the 3rd-millennium cal $\mathrm{BC}$ are available, corroborated by absolute dates, such as those obtained in the monuments of Azután [31] or Guadancil 3 [32] (Table 1). This is not so for Guadalperal, whose chronology was established in three phases: prior to the megalith, megalithic and Bell-Beaker period from the information compiled by Leisner and Leisner [34] which must be confirmed.
Throughout the Tagus basin (Fig. 2) we find varying concentrations and dispersions of tombs in different units of landscape [41]. In this case our interest centres on the dolmens (Fig. 3). Upstream the monument of Navalcán is located [42] also covered by the waters of a reservoir. The similarities between this site and that of Guadalperal are clear, particularly located at the entrance of the chamber). The workflowthe presence of conceptually similar decorative and architectural elements [43]. In an intermediate position between the two, although not flooded, the dolmen of Azután [31] is located, cited by H. Obermaier [33]. This monument presents an architecture of a similar nature to that of Guadalperal, with inner stones and a chamber made up of 14 slabs [31]. Finally,

Table 1 Absolute datings of the dolmens of the Spanish Tajo basin

\begin{tabular}{|c|c|c|c|c|}
\hline Site and reference & Absolute date (BP) & Lab reference & Material & Calibrated ( $2 \sigma \mathrm{cal} \mathrm{BC})$ \\
\hline \multirow[t]{2}{*}{ Azután [31] } & $5750 \pm 130$ & Ly-4578 & Human bone & $4904-4862$ \\
\hline & & & & $4856-4344$ \\
\hline Joaniña [36] & $5400 \pm 210$ & Sac-1380 & Charcoal & $4712-3771$ \\
\hline \multirow[t]{2}{*}{ Azután [31] } & $5250 \pm 40$ & Beta-157731 & Charcoal & $4231-4194$ \\
\hline & & & & $4170-3975$ \\
\hline \multirow[t]{2}{*}{ Azután [31] } & $5060 \pm 90$ & UGRA-288 & Human bone & $4041-4016$ \\
\hline & & & & 3995-3649 \\
\hline \multirow[t]{2}{*}{ Monteheremoso 8 [37] } & $5040 \pm 70$ & Ua-17768 & Charcoal & 3968-3699 \\
\hline & & & & $3686-3654$ \\
\hline Tremedal [38] & $5000 \pm 60$ & GrA-15903 & Charcoal & $3946-3653$ \\
\hline \multirow[t]{3}{*}{ Portillo de las Cortes [39] } & $5000 \pm 30$ & Beta-334952 & Human bone & 3943-3865 \\
\hline & & & & $3811-3701$ \\
\hline & & & & $3681-3655$ \\
\hline \multirow[t]{4}{*}{ Guadancil 3 [40] } & $5000 \pm 40$ & Beta-328111 & Charcoal & $3946-3856$ \\
\hline & & & & $3846-3834$ \\
\hline & & & & $3820-3696$ \\
\hline & & & & $3690-3653$ \\
\hline Montehermoso 11 [37] & $4965 \pm 75$ & Ua-17766 & Charcoal & $3946-3640$ \\
\hline \multirow[t]{3}{*}{ Montehermoso 11 [37] } & $4920 \pm 70$ & Ua-17763 & Charcoal & $3945-3857$ \\
\hline & & & & $3818-3622$ \\
\hline & & & & $3583-3531$ \\
\hline \multirow[t]{2}{*}{ Tremedal [39] } & $4860 \pm 50$ & GrA-15941 & Charcoal & $3765-3727$ \\
\hline & & & & $3715-3526$ \\
\hline \multirow[t]{2}{*}{ Azután [32] } & $4620 \pm 40$ & Beta-145277 & Human bone & $3522-3336$ \\
\hline & & & & $3211-3193$ \\
\hline \multirow[t]{4}{*}{ Azután [32] } & $4590 \pm 90$ & Ly-4500 & Human bone & $3626-3576$ \\
\hline & & & & $3571-3561$ \\
\hline & & & & $3534-3074$ \\
\hline & & & & $3066-3025$ \\
\hline \multirow[t]{2}{*}{ Trincones 1 [40] } & $3600 \pm 60$ & Beta-197160 & Sediment & 2138-1868 \\
\hline & & & & $1850-1771$ \\
\hline Joaniña [36] & $3480 \pm 170$ & Sac-1381 & Charcoal & $2287-1422$ \\
\hline
\end{tabular}




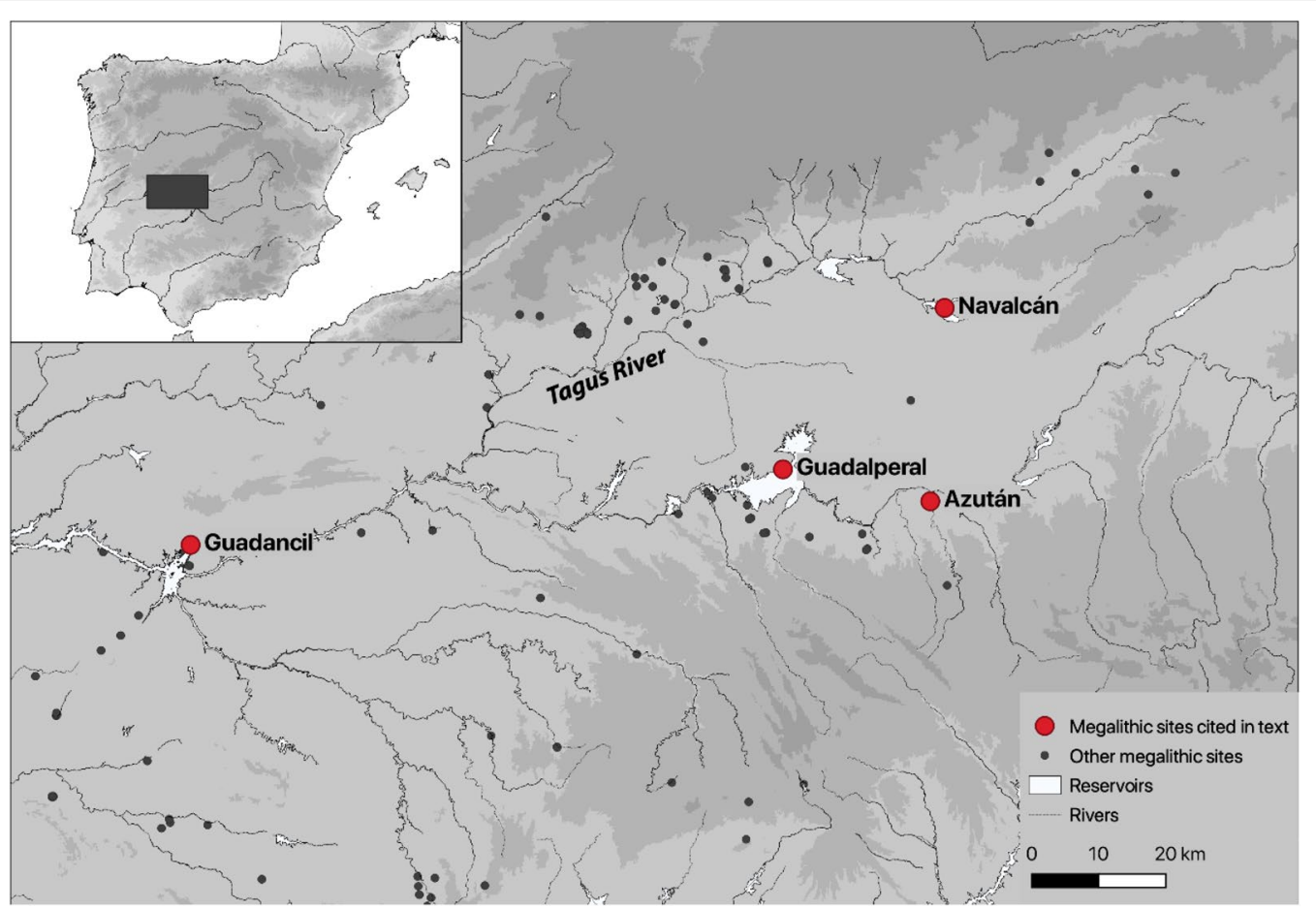

Fig. 2 Map of the section of the river Tajo (Spain) showing Guadalperal and other megalithic sites mentioned in Fig. 3. The cartographic

representation is comprised between the following geographical coordinates (WGS84 datum): 6.78 W, 40.08 N (upper left corner) and 4.41 W, $39.2 \mathrm{~N}$ (lower right corner)
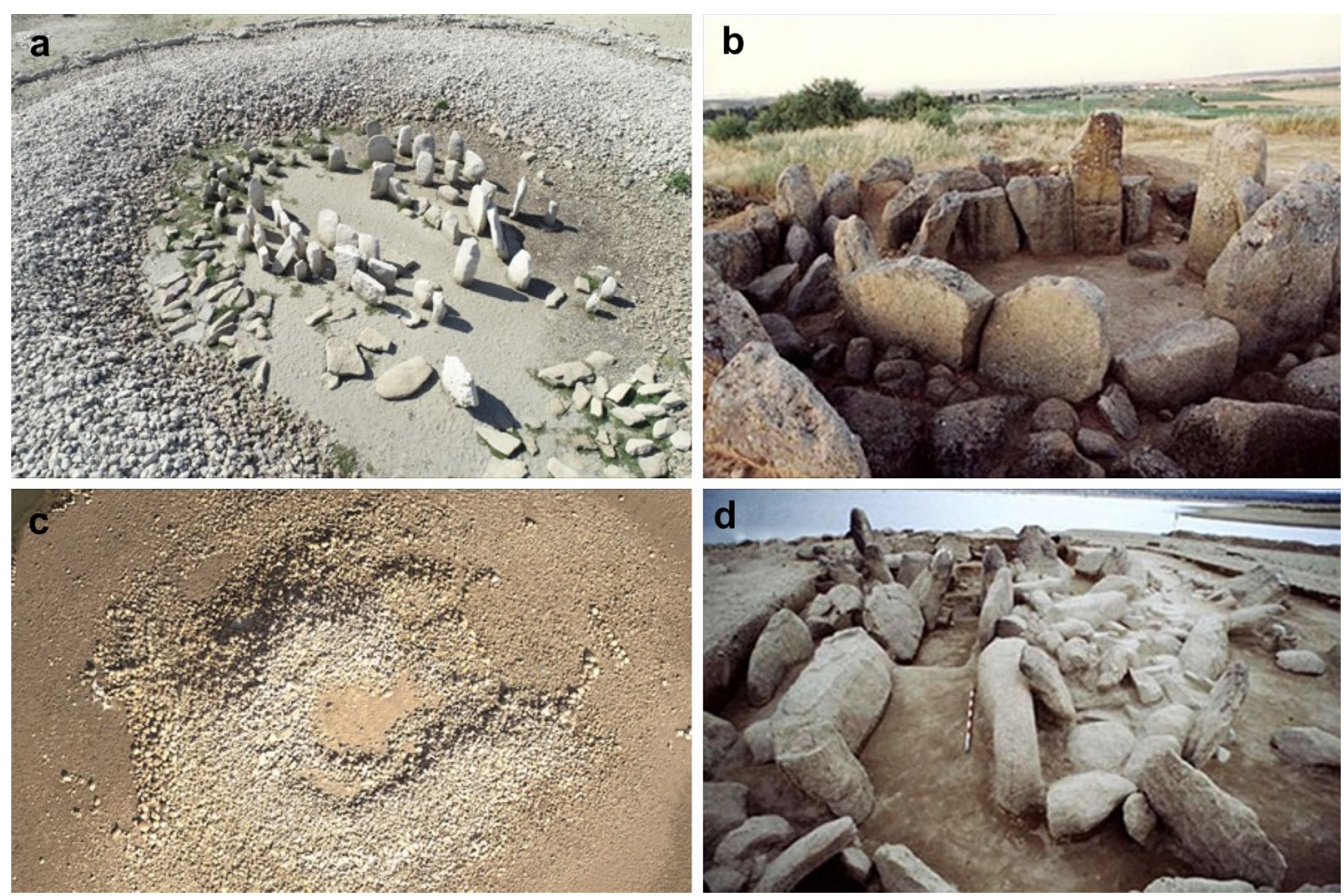

Fig. 3 Photographs of the megaliths mentioned in text. A Guadalperal in 2019 (flooded). B Azután during its excavation (not flooded). C View of the area of Guadancil 1 in 2012 (flooded). D General view of the dolmen of Navalcán during its excavation (flooded) 
beyond this site to the west is the necropolis of Guadancil [44] also submerged. The close relationship between the megaliths and the course of the Tagus River or its direct tributaries points to the relationship between river streams and prehistoric settlement, being a factor that has furthered the flooding of these sites once the dams were built.

The discovery and excavation of Guadalperal between 1925 and 1927 was the work of Hugo Obermaier [4549]. In 1936, Obermaier moved to Fribourg [46] during his fieldwork. The work concerning Guadalperal was published monographically years later after his death by Georg and Vera Leisner [33]. The site initially appeared as a large tumulus formed by quartzite from which some of the slabs forming the chamber appeared slightly. During the dig, the sediments and quartzite blocks that formed the mound were removed entirely and disposed around the chamber forming a circle, which left the structure of the dolmen free of its covering. The internal architecture was made up of a chamber, a corridor and atrium. The corridor, as far as can be gleaned from the photographs taken during the dig [33], was restored with concrete, although most of the slabs have now collapsed. Within the chamber, which may well have contained 12-14 slabs, from which only nine remain. The chamber was surrounded by a system of buttresses made mostly of slabs of the same size and material as those in the chamber. The slabs closer to those in the chamber are larger, while those further away are smaller and use materials of different nature such as quartzite. The stela at the entrance of the chamber [50] would have been originally located at a place nearby from it was erected and consolidated during Obermaier's work. Figure 4 shows the location of these elements on a current aerial image of the site.

Through the 1960s the massive construction of reservoirs was perceived in Spain as an opportunity for technological modernization $[51,52]$. Any assessment of the impact on cultural sites was reserved solely for those monuments that were regarded as masterpieces of Roman past [53]. On the other hand, innumerable sites of widely varying chronologies, such as megalithic monuments, were flooded without collecting any records of them. These decisions were taken considering a sparsely developed legislation dating back from 1933 [54] which failed to contemplate the impact of civil infrastructures on archaeological goods.

Guadalperal was flooded in 1969. It first re-emerged in 1992, when a graphic record was drawn up of the menhir-stela [43]. It did not reappear above the water again until the summer of 2019, which is when the site

Table 2 Specifications of the used hardware

\begin{tabular}{|c|c|c|}
\hline Device & Purpose & Specifications \\
\hline \multirow[t]{3}{*}{ Faro Focus 3D X330 (TLS) } & Recording of point clouds & Range: $0.6-330 \mathrm{~m}$ \\
\hline & & $\begin{array}{l}\text { Ranging error (systematic measu- } \\
\text { ment error at around } 10 \mathrm{~m} \text { and } \\
25 \mathrm{~m} \text { ): } \pm 2 \mathrm{~mm}\end{array}$ \\
\hline & & Measurement rate (pts/sec): 9,76,000 \\
\hline \multirow[t]{6}{*}{ DII Phantom 4 Pro (UAV) } & Aerial photogrammetry & $\begin{array}{l}\text { GPS-GLONASS positioning system }( \pm \\
0.5 \mathrm{~m} \text { vertical accuracy, } \pm 1.5 \text { horizontal } \\
\text { accuracy) }\end{array}$ \\
\hline & & Effective: pixels: 20 million \\
\hline & & Image sensor: one-inch CMOS sensor \\
\hline & & Image size: $5472 \times 3648$ pixels \\
\hline & & File format: JPEG \\
\hline & & Focal length (fixed): 8.8 mm \\
\hline \multirow[t]{5}{*}{ GoSCAN 50 (short-range scanner) } & Recording of point clouds & Range (recommended): 0.05-0.5 m \\
\hline & & Accuracy: $0.1 \mathrm{~mm}$ \\
\hline & & Resolution: $0.1 \mathrm{~mm}$ \\
\hline & & Measurement rate (pts/sec): 5,50,000 \\
\hline & & Scanning area: 143 × 108 mm \\
\hline \multirow[t]{5}{*}{ Nikon D5300 (camera) } & Close-range photogrammetry & Effective pixels: 24.2 million \\
\hline & & Image sensor: $23.5 \times 15.6$ CMOS sensor \\
\hline & & Image size: $6000 \times 4000$ pixels \\
\hline & & File format: NEF, 14 bit compressed \\
\hline & & Focal length (used): $18 \mathrm{~mm}$ \\
\hline
\end{tabular}




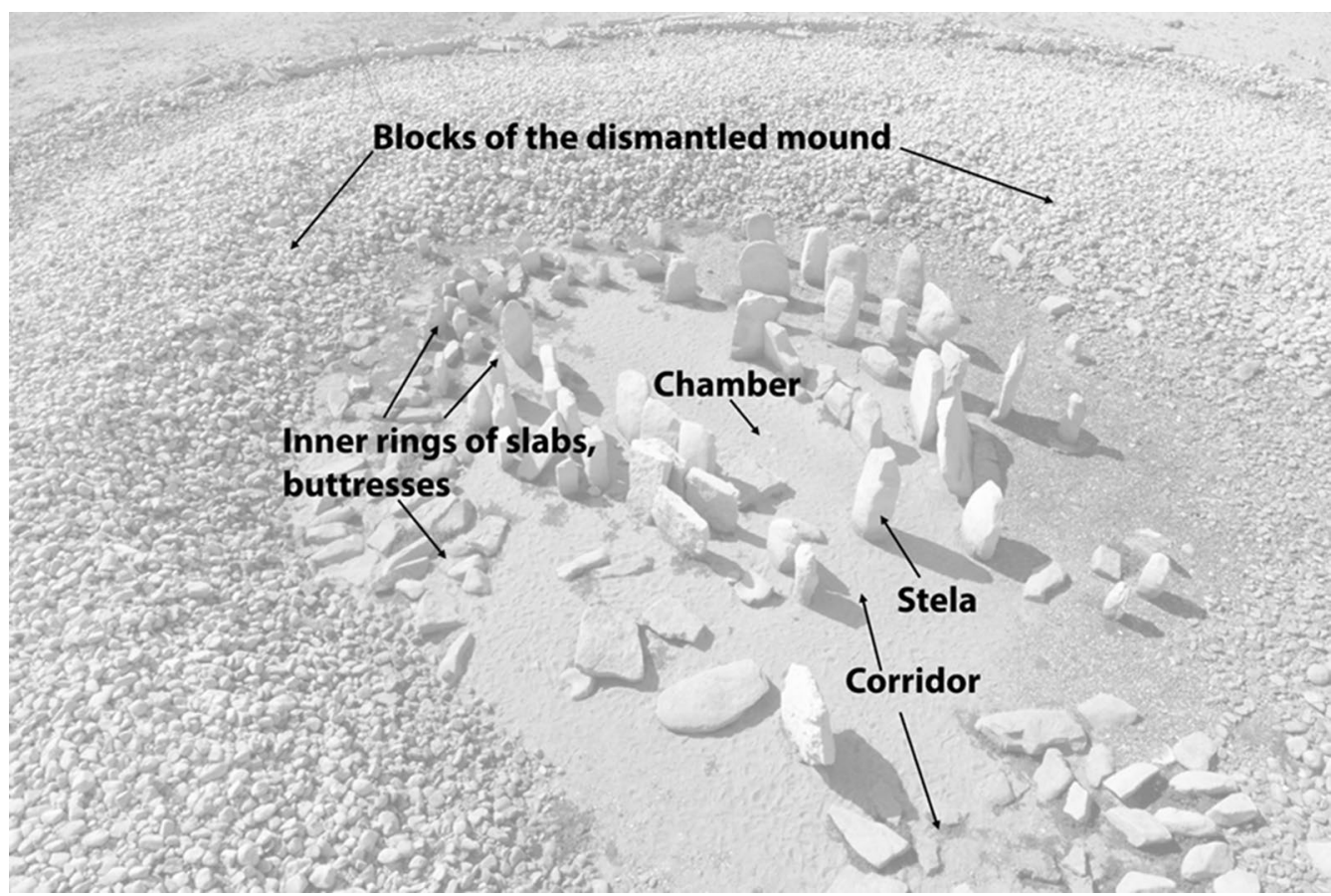

Fig. 4 The main architectural parts of the Guadalperal dolmen (Spain) described in the text on an aerial image of the year 2019

acquired its fame, and we were able to carry out the documentation presented here.

\section{Methods}

Digital documentation techniques can provide threedimensional models of archaeological elements in detail, being ideal for the study of an archaeological site whose access is limited or intricate. These techniques include, but are not limited to, unmanned aerial vehicles (UAV), terrestrial laser scanning (TLS), photogrammetry and short-range scan. For this study we can consider three ranges of documentation: (a) 'long-range', which refers to the element in its surroundings such that a digital model of the ground and a high-resolution orthophotograph are obtained; (b) 'medium-range', referring to a digital model in the form of a point cloud with a minimum density of $2.5 \mathrm{~mm}$ of the entire element, and precision lower than to $5 \mathrm{~mm}$; and (c) 'short-range', to obtain high-resolution digital models of singular elements within the structure (i.e., the stela located at the entrance of the chamber). The workflow is depicted in Fig. 5 Device specifications are given in Table 2.

\section{Terrestrial laser scanner (TLS)}

Terrestrial laser scanner is an instrument that facilitates 3D models of point clouds of an object at a distance from the equipment of between 0.6 and $300 \mathrm{~m}$. It is a commonly used technique in the documentation of heritage goods, buildings or infrastructure for academic study, records, intervention or preservation [55-58]. For the documentation of the dolmen in Guadalperal, a medium-long range scanner was used, with a capacity of 1 million points per second at a maximum distance of $330 \mathrm{~m}$ (Faro Focus 3D X330) [59, 60]. The documentation of the element is obtained from the capture of 3D spherical images taken from different positions. Work is structured according to a flow implemented by the authors $[58,61]$ the different takes using the spheres as reference points, thus obtaining a 3D point cloud model. Noise is cleaned and filtered out, including the effect of the edge of the elements on the monument or the "mirror effect" produced as a result of the reflection on certain surfaces at the moment of the scan.

\section{Photogrammetry using UAV}

The photogrammetry workflows of images captured from unmanned aerial vehicles have increased in archaeological studies due to both the improvements in spatial resolution and the fall in costs [62-67]. A detailed description of the state-of-art can be found elsewhere [68-79]. For image collection a drone DJI Phantom 4 Pro [80] was used with a GPS-GLONASS positioning system, a maximum flight time of around $25 \mathrm{~min}$, a triple-axis stabilizer, a frontal, lower and back vision system, a camera with a one-inch CMOS sensor, effectively $20 \mathrm{MP}$, image size 


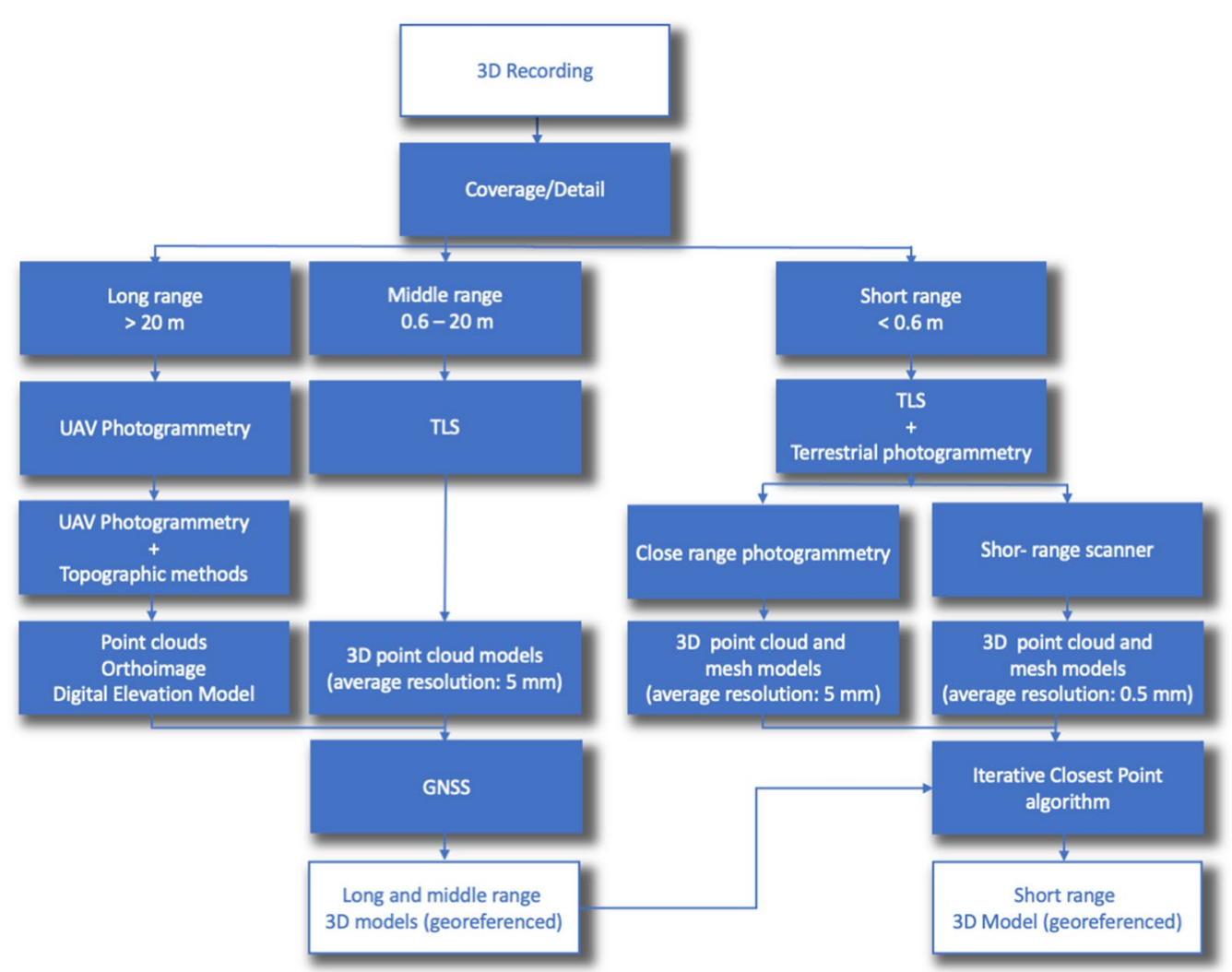

Fig. 5 Data processing workflow used in this article

of up to $5472 \times 3648$ pixels and the objective at a fixed focal distance of $8.8 \mathrm{~mm}$.

Two flights were planned: (a) aerial and zenithal photogrammetry surrounding the area of the dolmen at a mean altitude of $35 \mathrm{~m}(\mathrm{GSD}=1 \mathrm{~cm})$, longitudinal coverage of $85 \%$ and transversal of $65 \%$; (b) another with three circular orbits with a $15 \mathrm{~m}$ radius $(\mathrm{GSD}=0.4 \mathrm{~cm})$ at heights of 7, 16 and $23 \mathrm{~m}$, at speeds of 1,2 and $3 \mathrm{~s}$ to achieve coverage of $85 \%$ in the three orbits.

\section{Photogrammetry and short-range scanner}

The recording of the engraved supports is of particular interest as we knew of the existence of a stela located next to the entrance to the chamber of the dolmen [50, 71]. There are two possible ways of getting 3D models with optimal resolutions: digital photogrammetry and short-range scanner. Employing photogrammetry an individual survey was conducted on the most relevant supports, particularly the slabs that make up the chamber. The photogrammetry was performed using a conventional Nikon D5300 camera with a CMOS sensor of $24 \times 16 \mathrm{~mm}$, which produces images of 24 megapíxels $(6000 \times 4000$ pixels). To compare the previous results with a second source we used an additional technique on the front face of the menhir at the entrance to the dolmen. To do so, we used a short-range scanner, GoSCAN 50 with a maximum resolution of $0.5 \mathrm{~mm}$ and a precision of $0.2 \mathrm{~mm}$. This equipment is based on the technology of measurement using calibrated photogrammetric cameras and patterns of structured light beams [57]. This system is slow in comparison with photogrammetry, so its use was reserved for those surfaces where the engravings were evident. The result obtained is a mesh of triangles with the resolution required (maximum $0.5 \mathrm{~mm}$ ) textured with the original colour.

\section{Results}

The three ranges of documentation (long-mediumshort) were covered by the measurements taken. A digital model of the terrain and the dolmen from a zenithal plan were obtained using photogrammetry, as well as a highresolution orthophoto. TLS provided a 3D point cloud model of the element from a viewpoint on the ground. By putting together the photogrammetry and the shortrange scanner a high-resolution 3D model was generated of those parts of the structure requiring greater detail. 


\section{Terrestrial laser scanner}

For the full documentation of the dolmen, 36 independent takes were needed. These were performed using two scanners simultaneously over $4 \mathrm{~h}$ Regarding the estimation of errors in the joining of the point clouds, the RMSE was estimated at $4.76 \mathrm{~mm}$, with an average error of $4.4 \mathrm{~mm}$ and considering a total of 107 points.

The point cloud obtained contains 363 million points. For cleaning and filtering, point cloud classification algorithms from the software RealWorks ${ }^{\circledR}$ were used. Through automatic and manual filtering unwanted points were eliminated. These made up $2 \%$ of the total of 355 million points that the cloud was made up of. Figure 6 shows the point cloud after the noise had been eliminated and classified as follows: dolmen structure, dolmen ground and terrain. The point cloud generated is georeferenced in the ETRS89 UTM H30 system of coordinates with orthometric heights. The absolute accuracy was estimated using ground control points. The RMSE values after georeferencing the point cloud can be found in Table 3.

\section{Photogrammetry with UAV}

The necessary fieldwork was carried out to provide the photogrammetric block with enough spatial position points over the terrain, known as support points. A total of 15 such support points were distributed uniformly. At the same time as the photogrammetric support was marked, the coordinates were taken using a GPS LEICA 1200 by means of two bifrequency receptors using the static method. For the first zenithal flight five passes over
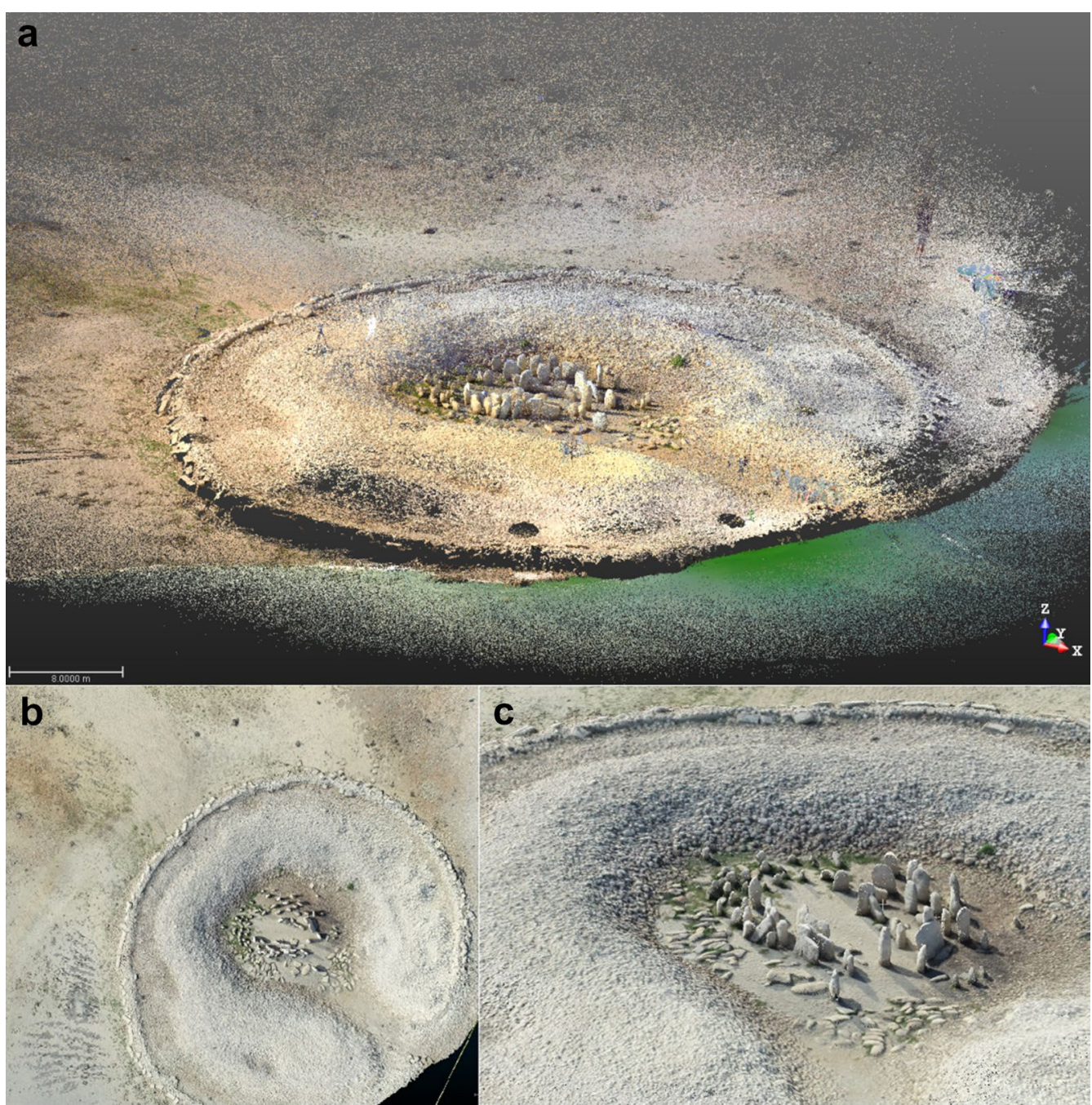

Fig. 6 Products obtained following the long-range procedure described in the documentation of the dolmen of Guadalperal. A Gross point cloud obtained using TLS. General views of the dense point cloud obtained by photogrammetry: plan (B) and perspective (C) 
Table 3 RMSE of the TLS-generated point cloud and of the adjustment of the two photogrammetric blocks

\begin{tabular}{llllll}
\hline Product & $\begin{array}{l}\text { Number of } \\
\text { points }\end{array}$ & $\mathrm{RMSE}_{\boldsymbol{x}}(\boldsymbol{m})$ & $\mathrm{RMSE}_{\mathbf{y}}(\boldsymbol{m})$ & $\mathrm{RMSE}_{\mathbf{z}}(\boldsymbol{m})$ & $\mathrm{RMSE}_{\mathbf{x y z}}(\boldsymbol{m})$ \\
\hline TLS point cloud (after georeferencing) & 11 & 0.007 & 0.004 & 0.008 & 0.004 \\
Zenital flight (block adjustment) & 9 & 0.012 & 0.024 & 0.024 & 0.036 \\
Circular convergent flight (block adjustment) & 8 & 0.009 & 0.019 & 0.015 & 0.025 \\
\hline
\end{tabular}

the site were made and a total of 170 photographs taken, and for the convergent orbital flight 169 photographs were obtained, distributed in three different orbital planes.

The photogrammetry was processed using the software Agisoft Metashape, based on the acquisition of great densities of points from the correlation [73-75]. This software was developed using the techniques and procedures applied in the field of computational vision and graphics, such as SfM and MVS, with which a 3D model is automatically obtained from multiple convergent images [76-78]. In this research the basic steps of workflow in Metashape were followed as described in the publication [79], paying particular attention to the process of error reduction in the disperse point cloud [79]. The photogrammetric blocks were adjusted separately for each of the planned flights. The results of the absolute accuracy estimation can be found in Table 3 .

Once the data from the flights had been fitted and optimized, they were joined together in a single block made up of 239 photographs and 11 ground control points. A total of 1,189,169 points of optimized links were used in this new model, model, resulting in a final fit of the block whose RMSE was $2.9 \mathrm{~cm}$. Once the definitive block had been formed, the dense point cloud was generated (Fig. 6) from a total of 10,278,770 points. These were then filtered and classified to eliminate the noise from various sources. From the resulting point cloud, the triangulation, the digital elevation model and the final orthophoto were generated with a resolution of $2 \mathrm{~cm}$.

\section{Photogrammetry and short-range scanner}

The number of images varied depending on the complexity, shape and size of the supports following the basic recommendations of the documentation through SfM. The data were processed using the software COLMAP [81, 82 ] in a cluster with 4 nodes equipped with GPUs. The software was configured to produce dense point clouds with the highest possible number of homologous points and with geometric filtering of information, a choice which reduces the number of possibly anomalous points. The result is a cloud of 35.9 million points with an average surface density of 12.86 points $/ \mathrm{mm}^{2}$ (standard deviation: 6.85).
The geometric documentation of the engravings on the menhir was also performed in a high-resolution survey using the short-range scanner $(0.5 \mathrm{~mm}$ precision), which provided 4 million points on the front face. The estimated average surface density of the 3D point cloud is 3.73 points $/ \mathrm{mm}^{2}$ (standard deviation: 0.56). To homogenize the point cloud derived from the photogrammetry we sampled it so that it had a minimum distance between points of $0.5 \mathrm{~cm}$. The result was a new point cloud with an average surface density of 2.93 points $/ \mathrm{mm}^{2}$ (standard deviation: 0.98 ), which can be better compared with the results of the short-range scanner. Additional file 1 includes a low-resolution version of this product.

The point clouds were scaled and georeferenced individually in the point clouds of the TLS such that each model of a slab had absolute coordinates (Fig. 7). This work was resolved using the Iterative Closest Point algorithm [83, 84] from the CloudCompare software. Iterative processes were set to reduce the RMS of the georeferencing below a threshold of the difference of $1 \mathrm{e}-06$, being the difference the distance between each point of the cloud derived from photogrammetry and its nearest neighbour in the TLS reference cloud. This approach rendered in all cases an RMS of less than $1 \mathrm{~cm}$ (average 0.47 ), calculated from 50,000 points.

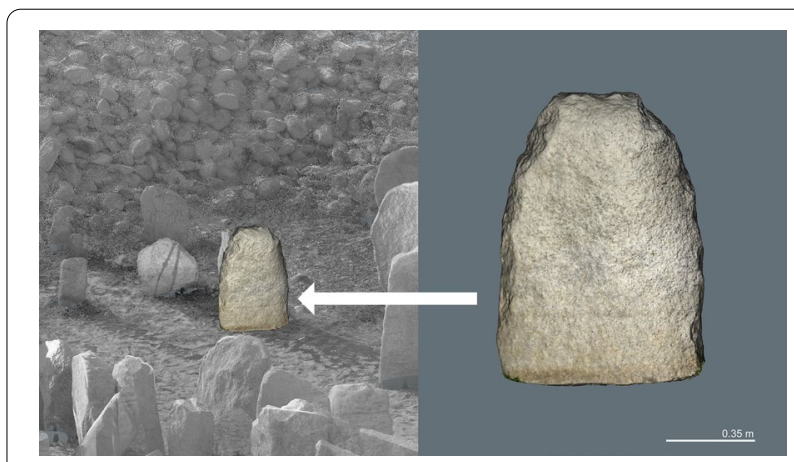

Fig. 7 Georeferencing of slabs point clouds generated by photogrammetry (right) on the overall point cloud obtained from TLS (left) using the Iterative Closest Point algorithm (RMS of the registration $0.34 \mathrm{~cm}$ ) 
Finally, to heighten the engravings, we applied the 3DMeshTracings methodology described in [27].

\section{Discussion}

By means of this detailed process, the 3D information of the documented element is available within the overall coordinates (ETRS89 UTM H30). The products obtained present the following advantages: (a) they supply data that make up for the lack of information on the archaeological site analysed to draw up fresh archaeological documentation, (b) they tackle the issue of the future monitoring of the site for any effects that changes in the reservoir may have on the structure of the dolmen, and (c) the model can be used for disseminating cultural contents. The first result is the availability of the documentation we provide, while the rest are perspectives which will need to be addressed in the future. Therefore, we centre our attention on the discussion regarding the progress made in the first point.

\section{The structure of the monument and its preservation}

The documentation generated effectively permits that the monument can be studied on a territorial level and compared with other monuments of the same nature. The photogrammetric and TLS data have served to create detailed cartography of the monument. The generation of sub-products has produced basic information, together with that described in "The archaeological and historiographic context of Guadalperal"Section, which is useful in the interpretation of the megalithic chamber (Fig. 8). The current location of the slabs and their comparison with the textual and graphical information facilitates the generation of thematic maps on the original position of the slabs and their evolution over time, such that it is feasible to perform a virtual anastylosis of the monument. Thus, the identification of the slabs has been carried out after a thorough inspection of the known historic planimetry and photographs [18] and their comparison with the 3D models. This process allows us to visualise the various degrees of intervention and conservation in the tomb in 1925, 1935 and 1955. Figure 9 depicts different aspects of the dolmen both from the information collected by Obermaier and its current state.

This thematic planimetry Fig. 8 allows us to organize the information to plan conservation actions, but also the possible archaeological works that could be carried out in the future. The preliminary conclusions of this work allow us to state that the restoration of Obermaier was centred on a massive reconstruction of the corridor and the fixing of certain slabs both of the chamber and the circles around it. The chamber and its most immediate interior rings are those that present an optimum level of preservation, while the most exterior rings and the corridor, partly made-up during Obermaier's restoration, are those that present the greatest structural damage.

Besides, this information serves to produce models simulating changes in conditions to which the supports of the monument have been subjected. Figure 10 shows the number of days that each part of the monument has been above water, information that can be obtained using historical data series of flooding and a precise survey. Using a Python script, we have associated the georeferenced height values of the point cloud with the historical data values of the reservoir water level in the period 1970-2019. These data allow us to visualise which specific areas of the monument are

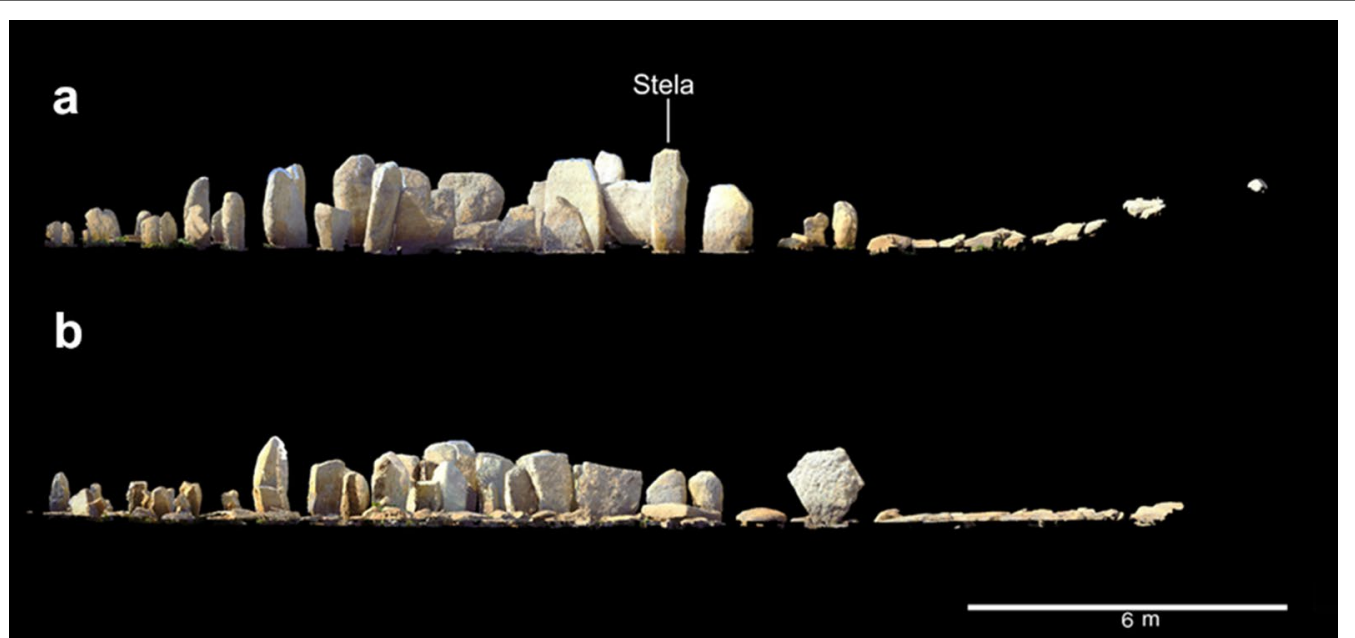

Fig. 8 Elevations of the construction of the Guadalperal dolmen generated from the point cloud. A North elevation showing the stela. B South elevation 


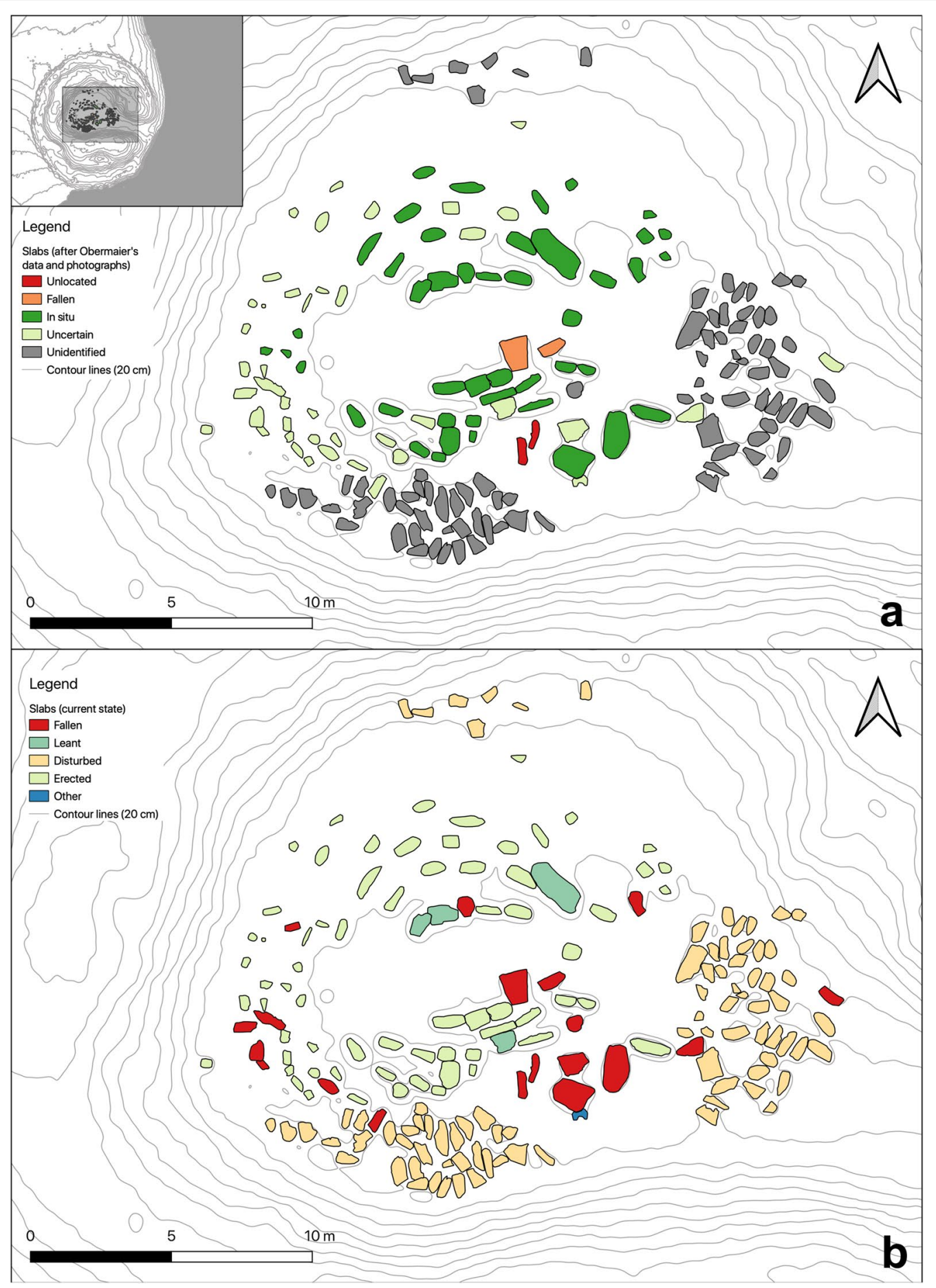

Fig. 9 Thematic planimetry generated after this study. A Slabs positions, after old data, B Current state of slabs

subject to the most drastic environmental changes, i.e., the variation from a dry environment to immersion in water. The data reveal a wide range of days (150-1500) in which the surfaces of the different slabs have been exposed out of the water. This resource will be used to monitor any possible conditions the dolmen may suffer and for the simulation of the effects of the reservoir on the materials. The study of the evolution of surface erosion can be carried out by creating new geometric 


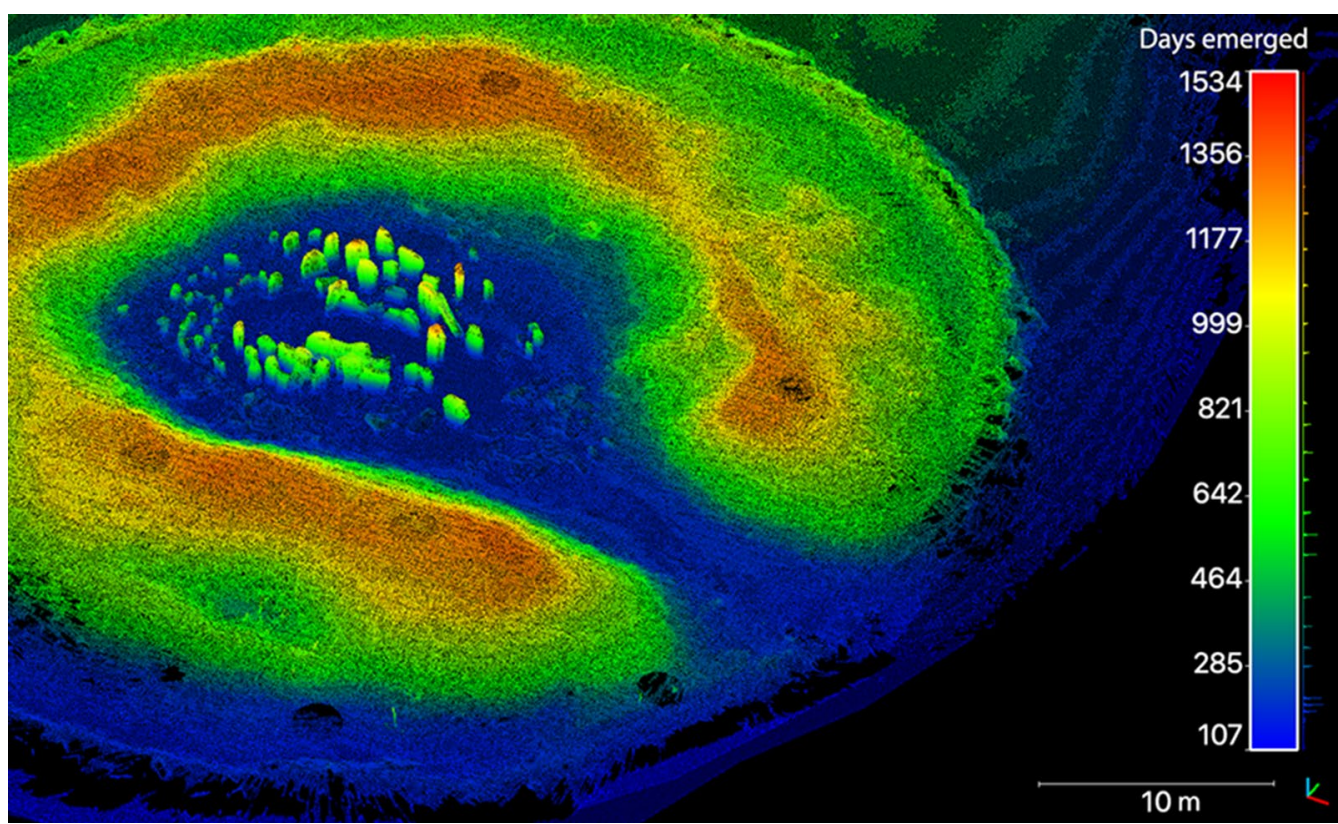

Fig. 10 Thematic point cloud of Guadalperal. The points have been classified by the number of days that its location have been emerged between 1970 and 2019. Historic data were provided by the Spanish Tagus River Hydrographic authority

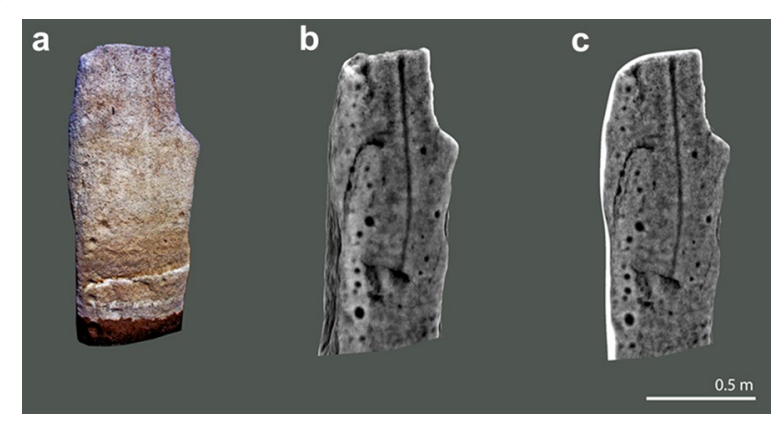

Fig. 11 Comparison between the photographic recording of the stela made in 1992 (a) and the 3D meshes produced in this work: $\mathbf{b}$ photogrammetry and $\mathbf{c}$ short-range scanner. $\mathbf{b}$ and $\mathbf{c}$ meshes have been obtained through the 3DMeshTracings procedure

models during future visits to the site, from which temporary erosion models can be derived.

\section{The recording of the engravings on the stela}

At short range, the products obtained allow the study of details of rock close to the limit of visual perception and the comparison of its degree of preservation and readability with the graphic supports obtained in 1992. The recording made at that time made it known that there was a stela-menhir at the entrance to the chamber. Its decoration could only be seen partially as the lower area was underwater. Its size was visible as well as the engravings accompanied by cupmarks on the northern face on the western face. The work carried out on the stela-menhir using both short-range laser scanner and digital photogrammetry is mutually coherent (Fig. 11), highlighting the same type of information in the engraved surfaces. It should only be noted that the linear distribution of the scanner observations provides a sharper reading of the engravings, to the detriment of photogrammetry, which has a higher density of points, but a more irregular distribution. With this study case, and without the space necessary to make a full comparison between the two methods, we can confirm that the capture by photogrammetry is significantly faster and more versatile, which suggests that it should be the technique of choice when documenting free-standing, multi-sided volumes of a certain complexity, such as the ones in question. In summary, the geometric information newly obtained adds complexity and sharpness to the information deriving from the tracings of 1992, which will be the subject of future publications.

The digital preservation of the supports seems, in this case, a fundamental necessity for the assessment of the erosion they are undergoing. For the moment this information is quite unequal, as it is only based on the comparison between the visualization of the geometric information collected and the photographs taken in 1992. Even so, the images we present permit the speculation that the decoration on the engraved pieces has not undergone considerable erosion over the last three decades. It will only be possible to extend this monitoring to 
the remaining supports in the future and base comparisons on the information we have generated in this study case.

\section{Conclusions}

Unfortunately, heritage management of reservoirs presents a fundamental inconveniency: the sheer number of archaeological sites in reservoirs is impossible to be quantified and it does not seem realistic to schedule a catch-all strategy of intervention on a set of goods with such different peculiarities, to which must be added any unexpected finds that might come to light in the coming years. These situations usually demand swift action, either because the sites are subject to a degree of degradation that cannot be estimated unless there exists a high-resolution recording of them, or because they cannot be visited except in short periods over many years. The latter is the case of the dolmen of Guadalperal. An effective solution is to adapt the documentation strategies to the particularities of each submerged archaeological site by means of an optimal three-dimensional recording.

Thanks to the application of the geometric documenting techniques used in Guadalperal we now can revisit the monument with the fidelity and quality that has not been possible until now. In this context, techniques for the digital documentation of heritage sites provide a diagnostic tool for alterations such sites have undergone, thus facilitating the decision-making process. More evidently, registering archaeological sites in high resolution permits the analysis of the information directly in the digital products, as is usual in European megalithic studies [24, 67-69]. The comparison of the documentation obtained with the dolmens in Fig. 1 seems the first activity to pursue.

Finally, such sites become a support that can easily be used in the social diffusion of contents that bring the good closer to the public who perceive it as something of its own $[53,85,86]$. Integrating all these perspectives in single documentation leads to the creation of support for the management of a scenario as complex as is that of submerged heritage.

\begin{abstract}
Abbreviations
UAV: Unmanned aerial vehicles; TLS: Terrestrial laser scanning; CMOS: Complementary metal-oxide-semiconductor; SfM: Structure from motion; MVS: Multiview stereo; RMSE: Root mean squared error; GCP: Ground control points.
\end{abstract}

\section{Supplementary Information}

The online version contains supplementary material available at https://doi. org/10.1186/s40494-021-00590-5.

Additional file 1. Point cloud of the Guadalperal dolmen. The density of points has been reduced to provide a better diffusion.

\section{Acknowledgements}

We also to thank Alicia Prada, Antonio González Cordero and Manuel Herrero for their collaboration during this work. We would like to acknowledge the two anonymous reviewers for their advice, which has enriched the final version of this paper.

\section{Authors' contributions}

Conceptualization, investigation, formal analysis, writing, fieldwork: ECC, JJSB, PBR, JAPA, RBB and MSF. Data processing: ECC, JJSB, JAPA and MSF. All authors read and approved the final manuscript.

\section{Funding}

This work has been Funded by the General Directorate of Fine Arts from the Ministry of Culture and Sports, through the General Subdirectorate of the Institute of Cultural Heritage of Spain through the project "Documentation and archaeological intervention in the Dolmen of Guadalperal and the basin of the Valdecañas Reservoir (Cáceres)" (2020-2021). We wish to thank the support of the Council for Culture and Sports from Extremadura regional government. Part of the photogrammetric works were supported by the computing facilities of Extremadura Research Centre for Advanced Technologies (CETA-CIEMAT), funded by the European Regional Development Fund. Also, thanks are extended to the Consejería de Economía e Infraestructuras (Junta de Extremadura) and European Regional Development Fund for funding through aid references GR18053 to the NEXUS Research Group (University of Extremadura).

Availability of data and materials

A low-resolution point cloud of the original data has been included as supplementary material.

\section{Declarations}

\section{Competing interests}

The authors declare that they have no competing interests.

\section{Author details}

${ }^{1}$ Department of Prehistory, Ancient History and Archaeology, Complutense University of Madrid, Madrid, Spain. ${ }^{2}$ Department of Graphic Expression, INTERRA Research Institute for Sustainable Territorial Development, NEXUS Research Group Engineering, Territory and Heritage, University of Extremadura, Cáceres, Spain. ${ }^{3}$ Prehistory Section. Department of History and Philosophy, University of Alcalá. Alcalá de Henares, Madrid, Spain. ${ }^{4}$ Department of Graphic Expression, INTERRA Research Institute for Sustainable Territorial Development, NEXUS Research Group Engineering, Territory and Heritage, University of Extremadura, Mérida, Spain.

Received: 15 May 2021 Accepted: 3 September 2021

Published online: 17 September 2021

\section{References}

1. Bueno-Ramírez P, de Balbín-Behrmann R, Barroso-Bermejo R, Laporte L, Gouezin P, Cousseau F, et al. From pigment to symbol: the role of paintings in the ideological construction of European megaliths. In: Müller J, Hinz M, Wunderlich M, editors., et al., Megaliths-societies-landscapes. Early monumentality and social differentiation in neolithic Europe. Bonn: Dr. Rudolf Habelt GmbH PP; 2019. p. 845-64.

2. Schulz PB. Radiocarbon dates and Bayesian modeling support maritime diffusion model for megaliths in Europe. Proc Natl Acad Sci USA. 2019;116:3460-5.

3. Finlayson B, Dennis S. Landscape, archaeology and heritage. Levant. 2002;34:219-27.

4. Krzemińska AE, Dzikowska A, Zarȩba AD, Jarosz KR, Widawski K, Lach JS. The significance of megalithic monuments in the process of place identity creation and in tourism development. Open Geosci De Gruyter. 2018;10:504-16.

5. Beck J, Chrisomalis S. Landscape archaeology, paganism, and the interpretation of megaliths. Pomegranate Int J Pagan Stud. 2009;10(2):142-62. 
6. Graham BJ. Heritage conservation and revisionist and nationalism in Ireland. Building a new heritage: tourism, culture and identity in the new Europe. Milton Park: Routledge; 1994. p. 133-58.

7. Grigoryev AA, Larchenko LV, Paranina AN, Bogdanov NA. Prehistoric stone objects of cultural heritage as a resource for the development of tourism in the Russian Arctic. IOP Conf Ser Earth Environ Sci. 2020;539(1):012093.

8. Robb J. Hegemonic megaliths: changing the Irish prehistoric. Ir Stud Rev. 1999;7:5-11.

9. Schierhold K. Westphalian megaliths go touristic: archaeological research as a base for the development of tourism. Feasible management of archaeological heritage sites open to tourism. Cham: Springer; 2018. p. 141-9.

10. Ross D, Saxena G. Participative co-creation of archaeological heritage: case insights on creative tourism in Alentejo, Portugal. Ann Tour Res. 2019. https://doi.org/10.1016/j.annals.2019.102790.

11. Benlloch PO, López-Romero E, Daire M-Y. Coastal erosion and public archaeology in Brittany, France. In: López-Romero E, Daire M-Y, Dawson T, Nimura C, editors. Public archaeology and climate change. 1st ed. Oxford: Oxbow Books; 2017. p. 81-9.

12. López-Romero E, Vázquez XIV, Mañana-Borrazás P, Güimil-Fariña A Recovering information from eroding and destroyed coastal archaeological sites: public archaeology and climate change. Oxford: Oxbow books; 2017. p. 72-80.

13. Grøntoft T, Cassar JA. An assessment of the contribution of air pollution to the weathering of limestone heritage in Malta. Environ Earth Sci. 2020;79:1-16.

14. Smith M, Speiran S, Graham P. Megaliths, material engagement, and the atmospherics of neo-lithic ethics: presage for the end(s) of tourism. J Sustain Tour. 2021;2-3:337-52.

15. Dawson T, Hambly J, Kelley A, Lees W, Miller S. Coastal heritage, global climate change, public engagement, and citizen science. PNAS. 2020;117(15):8280-6.

16. Fatorić S, Seekamp E. Knowledge co-production in climate adaptation planning of archaeological sites. J Coast Conserv. 2019;23:689-98.

17. Lecari N, Shulze J, Wendrich W, Porter B, Burton M, Levy TE. 3-D digital preservation of at-risk global cultural heritage. In: Catalano CE, De Luca $L$, editors. Eurographics workshop on graphics and cultural heritage. Merced: UC Merced; 2016.

18. Savage SH, Johnson A, Levy TE. TerraWatchers, crowdsourcing, and at-risk world heritage in the Middle East. In: Vincent M, López-Menchero Bendicho V, loannides M, Levy T, editors. Heritage and archaeology in the digital age. Cham: Springer; 2016. p. 67-77.

19. López RE, Mañana-Borrazás P, Güimil-Fariña A, Daire MY. Archaeology and coastal erosion: monitoring change through 3D digital techniques. In: Kamermans H, de Neef E, Piccoli C, Posluschny AG, Scopigno R, editors. The three dimensions of archaeology. Proceedings of the XVII UISPP World Congress (1-7 September, Burgos, Spain). Volume 7/Sessions A4b and A12. Oxford: Archaeopress; 2016. p. 90-7.

20. Reeder LA, RickTC, Landson JM. Our disappearing past: a GIS analysis of the vulnerability of coastal archaeological resources in California's Santa Barbara Channel region. J Coast Conserv. 2012;16:187-97.

21. Benavides López JA, Aranda Jiménez G, Sánchez Romero M, Alarcón García E, Fernández Martín S, Lozano Medina A, Esquivel Guerrero JA. 3D modelling in archaeology: the application of structure from motion methods to the study of the megalithic necropolis of Panoria (Granada, Spain). J Archaeo Sci: Rep. 2016;10:495-506.

22. Benavides López JA, Esquivel Sánchez JF, Esquivel Guerrero JA. Nuevas aportaciones al estudio métrico y geométrico del dolmen de Viera (Antequera, Andalucía). Menga Rev Prehist Andal. 2015;76:201-8.

23. Cassen S, Lescop L, Grimaud V. Pour une critique de la représentation tridimensionelle des architectures mégalithiques en Europe occidentale méthodes et usages actuelles. Ann Bretag Pays I'Ouest. 2013;120(1):7-35.

24. Moyano J, Odriozola CP, Nieto-Julián JE, Vargas JM, Barrera JA, León J. Bringing BIM to archaeological heritage: interdisciplinary method/strategy and accuracy applied to a megalithic monument of the Copper Age. J Cult Herit. 2020;45:303-14.

25. González-García AC, Vilas-Estévez B, López-Romero E, Mañana-Borrazás P. Domesticating light and shadows in the neolithic: the dombate passage grave (A Coruña, Spain). Cambr Archaeo J. 2019;29(2):327-43.

26. Cortón Noya N, López García A, Carrera RF. Combining photogrammetry and photographic enhancement techniques for the recording of megalithic art in north-west Iberia. Digit Appl Archaeo Cult Herit. 2015;2:89-101.

27. Cerrillo-Cuenca E, Bueno-Ramírez P, de Balbín-Behrmann R. "3DMeshTracings": a protocol for the digital recording of prehistoric art. Its application at Almendres cromlech (Évora, Portugal). J Archaeol Sci Rep. 2019;25:171-83.

28. Cassen S, Robin G. Recording art on neolithic stelae and passage tombs from digital photographs. J Archaeol Method Theory. 2010;17:1-14.

29. Cassen S, Lescop L, Grimaud V, Robin G. Complementarity of acquisition techniques for the documentation of Neolithic engravings: lasergrammetric and photographic recording in Gavrinis passage tomb (Brittany, France). J Archaeol Sci. 2014:45:126-40.

30. Williams K, Twohig ES. From sketchbook to structure from motion: recording prehistoric carvings in Ireland. Digit Appl Archaeo Cult Herit. 2015;2:120-31.

31. Bueno-Ramírez P, Barroso-Bermejo R, de Balbín-Behrmann R. Between east and west: megaliths in the centre of the Iberian Peninsula. In: Laporte L, Scarre C, editors. Megal Archit Eur. Oxford: Oxbow Books; 2016. p. 157.

32. Bueno-Ramírez P, Barroso-Bermejo R, de Balbín-Behrmann R. El dolmen de Azután (Toledo): áreas de habitación y áreas funerarias en la cuenca interior del Tajo. Alcalá: Univ; 2005.

33. Cerrillo CE. Una biografía de la necrópolis megalítica del área de Alconétar. Ataecina 10. Mérida: Instituto de Arqueología. Mérida: Consorcio de la ciudad Monumental de Mérida; 2018

34. Leisner G, Leisner V. El Guadalperal. Madr Mitt. 1960;1:20-73.

35. Bronk RC, Heaton T, Blaauw M, Blackwell P, Reimer P, Reimer R, et al. Statistical approaches and tools for IntCal20. Glasgow: EGU General Assembly Conference Abstract; 2020. p. 9336.

36. Reimer PJ, Austin WEN, Bard E, Bayliss A, Blackwell PG, Bronk Ramsey C, et al. The IntCal20 Northern Hemisphere radiocarbon age calibration curve (0-55 cal kBP). Radiocarbon. 2020;62:725-57.

37. Oliveira J. Monumentos megalíticos da bacia hidrográfica do rio server. Lisboa: Colibri; 1998.

38. Señorán MJM. Landscapes on the move. Digitally exploring the relationship between megaliths and mobility in Northern Cáceres (Spain). In: Mayoral Herrera V, Parcero-Oubiña C, Fábrega-Álvarez P, editors. Archaeol geomatics harvest benefits 10 years train Iberian peninsula. Leiden: Sidestone Press; 2018. p. 107-20.

39. Ruiz-Gálvez Priego ML. El conjunto dolménico de la Dehesa Boyal de Montehermoso. Extrem Arqueol. 2000;8:187-208.

40. Bueno-Ramírez P, Barroso-Bermejo R, de Balbín-Behrmann R, González Martín A, Cambra-Moo O, García Gil O, et al. Pasados releídos: el dolmen del Portillo de las Cortes, Guadalajara/MAN. Boletín Mus Arqueol Nac. 2016:31:9-28

41. Bueno-Ramírez P, Barroso-Bermejo R, de Balbín-Behrmann R. Construcciones megalíticas avanzadas de la cuenca interior del Tajo: el núcleo cacereño. SPAL. 2004. https://doi.org/10.12795/spal.2004.i13.03.

42. Cerrillo-Cuenca E, Bueno-Ramírez P. Counting with the invisible record? The role of LiDAR in the interpretation of megalithic landscapes in southwestern Iberia (Extremadura, Alentejo and Beira Baixa). Archaeol Prospect. 2019;26:251-64.

43. Bueno-Ramírez P, de Balbín BR, Barroso-Bermejo R, Alcolea González JJ, Villa R, Moraleda A. El dolmen de Navalcán. El poblamiento megalítico en el Guadyerbas. Toledo: Instituto Provincial de Investigaciones y Estudios Toledanos. Diputación de Toledo; 1999.

44. Bueno-Ramírez P, de Balbín BR. La graphie du serpent dans la culture mégalithique péninsulaire. Représentation de plein air et représentations dolméniques. L'Anthropologie. 1995;99:357-81.

45. Cerrillo Cuenca E, Liceras Garrido R, Prada GA. Tiempo y paisaje en la necrópolis megalítica de Guadancil (Cáceres). In: Rocha L, Bueno-Ramírez P, Branco G, editors. Death as archaeology of transition: thoughts and materials papers from the II International Conference of Transition Archaeology: death as archaeology of transition, 2013 (BAR International Series 2708). Oxford: Archaeopress; 2016. p. 71-81.

46. Moure RJA. Hugo Obermaier la institucionalización de las investigaciones y la integración de los estudios de prehistoria en la Universidad española. In: El hombre fosil 80 años después. Vol Conmem del 50 aniversario la muerte Hugo Obermaier. Oviedo: University of Oviedo; 1996. p. 17-50. 
47. Almagro GM. Hugo Obermaier y la prehistoria en España. In: Marzoli D, Maier J, Schattner TG, editors. Hist del inst arqueol alemán madrid faszikel 1 antecedentes y form del dep Madrid. Madrid: DAl; 2014. p. 167-86.

48. Obermaier H. El Dolmen de matarrubilla (Sevilla). Spain: Junta para Ampliación de Estudios e Investigaciones Científicas; 1919.

49. Obermaier H. Die Dolmen Spaniens. Im selbstverlage der anthropologischen gesellschaft. Munster: University of Munster; 1920.

50. de Balbín-Behrmann R, Bueno-Ramírez P. Soto, un ejemplo de arte megalítico al Suroeste de la Península. In: El hombre fosil 80 años después. Vol conmem del 50 aniversario la muerte Hugo Obermaier. Oviedo: University of Oviedo; 1996. p. 467-503.

51. Bueno-Ramírez P, de Balbín-Behrmann R. L'art mégalithique dans la Péninsule Ibérique: une vue d'ensemble. L'Anthropol. 1992;16:499-571.

52. Brendel B. Dam construction in Francoist Spain in the 1950s and 1960s: negotiating the future and the past. Sustain Dev. 2020;28:396-404.

53. Swyngedouw E. Technonatural revolutions: the scalar politics of Franco's hydro-social dream for Spain, 1939-1975. Trans Inst Br Geogr. 2007;32:9-28.

54. Coder PM, Moliner BC. La situación del patrimonio arqueológico subacuático en la cuenca extremeña del Tajo. Perspectivas de conservación, documentación y análisis. Arqueol Subacuát Esp Actas Congr Arqueol Naútica Subacuát Esp. 2013;2014(34):67-80.

55. Querol MA. Manual de gestión del patrimonio cultural. Madrid: Akal textos; 2010.

56. Fernández MS, Cortés JP, Gómez JN. Análisis geométrico para evaluación structural. TLS vs photogrametría terrestre: aplicación a puente de fábrica (EX-100PK-8). Rehabend 2016 Euro-American Congress. Construction pathology, rehabilitation technology and heritage management. Mexico: Instituto Tecnológico de la Construcción; 2016. p. 736-45.

57. Fryskowska A, Walczykowski P, Delis P, Wojtkowska M. ALS and TLS data fusion in cultural heritage documentation and modeling. Int Arch Photogramm Remote Sens Spat Inf Sci. 2015;40:147.

58. Kushwaha SKP, Dayal KR, Raghavendra S, Pande H, Tiwari PS, Agrawal S, et al. 3D digital documentation of a cultural heritage site using terrestrial laser scanner-a case study. Appl Geomatics Civ Eng. 2020. https://doi. org/10.1007/978-981-13-7067-0_3.

59. Monego M, Menin A, Fabris M, Achilli V. 3D survey of Sarno Baths (Pompeii) by integrated geomatic methodologies. J Cult Herit. 2019;40:240-6.

60. Faro Focus. Faro Focus 3D X330. Lake Mary: Faro Technologies; 2017

61. Faro SCENE. Faro. Lake Mary: Faro Technologies; 2019.

62. Sánchez-Fernández M, Chorro FJ, Marín M-J, de Sanjosé-Blasco JJ, Martínez LF. Gestión de los datos en proyectos "Scan to HBIM." Logroño: INGEGRAF; 2019.

63. Agudo PU, Pajas JA, Pérez-Cabello F, Redón JV, Lebrón BE. The potential of drones and sensors to enhance detection of archaeological cropmarks: a comparative study between multi-spectral and thermal imagery. Drones. 2018;2:1-23.

64. Luo L, Wang X, Guo H, Lasaponara R, Zong X, Masini N, et al. Airborne and spaceborne remote sensing for archaeological and cultural heritage applications: a review of the century (1907-2017). Remote Sens Environ. 2019;232:111280.

65. Pérez-Alvárez JA, Gonçalves GR, Cerrillo-Cuenca E. A protocol for mapping archaeological sites through aerial 4k videos. Digit Appl Archaeol Cult Herit. 2019;13:e00101.

66. Waagen J. New technology and archaeological practice. Improving the primary archaeological recording process in excavation by means of UAS photogrammetry. J Archaeol Sci. 2019;101:11-20.

67. Monna F, Magail J, Rolland T, Navarro N, Wilczek J, Gantulga JO, et al. Machine learning for rapid mapping of archaeological structures made of dry stones-example of burial monuments from the Khirgisuur culture, Mongolia. J Cult Herit. 2020;43:118-28.

68. Martínez-del-Pozo JÁ, Cerrillo-Cuenca E, Salas-Tovar E. Low altitude aerial photography applications for digital surface models creation in archaeology. Trans GIS. 2013;17(2):227-46.

69. Colomina I, Molina P. Unmanned aerial systems for photogrammetry and remote sensing: a review. ISPRS J Photogramm Remote Sens. 2014 https://doi.org/10.1016/j.isprsjprs.2014.02.013.

70. Kardasz P, Doskocz J. Drones and possibilities of their using. J Civ Environ Eng. 2016;6(3):1-7.

71. Campana S. Drones in archaeology state-of-the-art and future perspectives. Archaeol Prospect. 2017:24:275-96.

72. Bueno-Ramírez P, de Balbín-Behrmann R. Arte megalítico en la Extremadura española. Extrem Arqueol. 2000;8:345-80.

73. CREAFORM. GoSCAN50. Creaform: Levis; 2017.

74. Koutsoudis A, Vidmar B, loannakis G, Arnaoutoglou F, Pavlidis G, Chamzas C. Multi-image 3D reconstruction data evaluation. J Cult Herit. 2014;15:73-9.

75. Fernández-Hernandez J, González-Aguilera D, Rodríguez-Gonzálvez P, Mancera-Taboada J. Image-based modelling from unmanned aerial vehicle (UAV) photogrammetry: an effective. Low Cost Tool Archaeol Appl Archaeom. 2015;57(1):128-45.

76. Gonçalves JA, Henriques R. UAV photogrammetry for topographic monitoring of coastal areas. ISPRS J Photogramm Remote Sens. 2015:104:101-11.

77. Andersen NH. Causeway enclosures and megalithic monuments as media for shaping neolithic identities. In: Furholt M, Lüth F, Müller J, editors. Megaliths and identities. Boon: Habelt; 2011. p. 143-54.

78. Kyriakaki G, Doulamis A, Doulamis N, loannides M, Makantasis K, Proto-

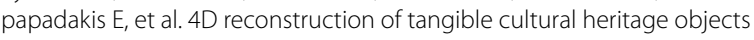
from web-retrieved images. Int J Herit Digit Era. 2014;3:431-51.

79. Smith MW, Carrivick JL, Quincey DJ. Structure from motion photogrammetry in physical geography. Prog Phys Geogr. 2014;38:97-116.

80. Mayer C, Pereira LG, Kersten TP. A comprehensive workflow to process UAV images for the efficient production of accurate geo-information. IX Natl Conf Cartogr Geod. 2018. https://doi.org/10.1201/b22212-21.

81. Phantom 4 PRO/PRO+. User manual v1.0. DJ: Nanshan; 2016.

82. Schonberger JL, Frahm J-M. Structure-from-motion revisited. 2016 IEEE Conf Comput Vis Pattern Recognit. 2016. https://doi.org/10.1109/ACCESS. 2018.2879337

83. Schönberger $J$, Zheng E, Frahm JM, Pollefeys M. Pixelwise view selection for unstructured multi-view stereo. Lect Notes Comput Sci. 2016. https:// doi.org/10.1007/978-3-319-46487-9_31.

84. Arun KS, Huang TS, Blostein SD. Least-squares fitting of two 3-D point sets. IEEE Transac Pattern Anal Mach Intelli PAMI. 1987;9(5):698-700.

85. Besl PJ, McKay ND. A method for registration of 3-D shapes. IEEE Transac Pattern Anal Mach Intelli. 1992;14(2):239-56.

86. Cerrillo-Cuenca E, Sanjosé J. Mapping and interpreting vanished archaeological features using historical aerial photogrammes and digital photogrammetry. Proceedings of the 38th Annual Conference on computer applications and quantitative methods in archaeology CAA2010. Oxford: Archaeopress; 2013. p. 43-6.

\section{Publisher's Note}

Springer Nature remains neutral with regard to jurisdictional claims in published maps and institutional affiliations. 